\title{
Ethnicity and (Dis)advantage: Exchanging Cultural Capital in UK International Education and Graduate Employment
}

\author{
by I Lin Sin \\ Independent Scholar \\ Sociological Research Online, 21 (4), 3 \\ <http://www.socresonline.org.uk/21/4/3.html> \\ DOI: $10.5153 /$ sro.4070
}

Received: 26 Mar 2016 I Accepted: 18 Oct 2016 I Published: 30 Nov 2016

\begin{abstract}
This article investigates the under-researched role of ethnicity in the conversion of cultural capital linked to UK international education into life chance privileges and disadvantages. It reports findings from qualitative interviews with Malaysian international students and graduates who pursued their UK education in the UK and/or in Malaysia. It moves beyond a heavy focus on class in existing literature to delayer further complexities in distinction influenced by ethnicity and made more visible by new modes of international education alongside the traditional mode. I highlight how ethnicity influenced the participants' higher education choices, and their accumulation and activation of knowledge, skills, dispositions and networks. I show how ethnicity shaped their sense of appropriate graduate work and their perceived value of a UK education in relation to economic opportunities and constraints. The participants tended to study, interact and work most with members of their ethnic group, reflecting Malaysia's distinctive majority-minority divide across higher education and employment. While linked to ethnicity, relevant participants regarded nationality as a more significant factor for exclusion in the UK labour market. The findings have implications for the development of Bourdieu's concept of cultural capital, and the advancement of equity and inclusiveness within and beyond international education. I conclude that more recognition is needed of the heterogeneity of the foreign student and graduate middle-class to explore the exchangeability of cultural capital across stratified geographical and sociorelational contexts.
\end{abstract}

\section{Keywords: Cultural Capital, Ethnicity, Bourdieu, Malaysia, International Education, Graduate Employment}

\section{Introduction}

There is growing interest within higher education literature to explore the relevance of Bourdieu's concept of cultural capital in the context of a rapidly expanding global academic marketplace. Bourdieu (1984) famously argued that individuals of economically advantaged backgrounds in 1950s and 1960s France had better access through their families to dominant cultural capital in forms such as high-status attributes, knowledge, style and taste. Their cultural capital enabled them to successfully navigate the school system which governed by the norms of the privileged class, rewarded their elite competences (Bourdieu \& Passeron 1977). This ensured their high academic performance and inter-generational reproduction of academic, occupational and social advantages. It helped the dominant class to maintain distinction from lower class individuals and their families who did not possess the same cultural capital within the given structure of relations which Bourdieu (1998) termed, the field. by social capital, the relationships and connections of support and recognition that individuals developed through membership and interaction with familial and institutional networks (Bourdieu 1997). Recent studies (Waters \& Leung 2013, 2012; Waters 2006; Kim 2011; Sin 2013, 2009; Gu \& Schweisfurth 2015) have extended Bourdieu's concept of cultural capital to include exclusive foreign or global cultural capital: globally-oriented and cosmopolitan knowledge, skills and dispositions obtained through international education and which can be mobilised to obtain distinction, specifically, superior employment and prestige. The focus was on the prominent trend of middle-class Asian foreign students pursuing Western tertiary international education in the host and/or the home country. While the significance of class in cultural capital pursuits is well-established in works such as 
these, ethnicity and other social divisions generally lack equal attention. This underplays the role of other key categories of social differentiation in the conversion of cultural capital into privileges and disadvantages in international education and graduate work. This article aims to address the gap on the interconnections between ethnicity, cultural capital and (dis)advantage. It draws on interview findings from a study on the middle-class distinction of Malaysians, the United Kingdom's largest source of UK and overseas-based international students from South East Asia (British Council 2014; UNESCO Institute for Statistics 2014).

1.3 My research investigated the link between cultural capital, obtained through UK international education, and the occupational and status advancement of Malaysian students and recent graduates. The focus of this article is on one aspect of the study related to the ways in which ethnicity framed my participants' higher education choices and their accumulation as well as activation of education-related cultural capital. My argument is that the foreign student and graduate middle-class is diverse and whose practices of distinction have to be read beyond a Bourdieusian focus on class. This is because cultural capital enhanced through international education does not produce equal outcomes for all as its exchange value is mediated by various other social divisions. I argue that exploring the dynamics of ethnicity is one way to gain deeper appreciation of the individual and contextual specificities that influence how education-related cultural capital is acquired and employed in stratified spheres and spaces. With regards to the Malaysian context, I argue that class has to be considered in conjunction with ethnicity, given that they are the two main divisions which cut across Malaysian society and which are especially prevalent in higher education and employment.

My discussion of research findings will show that my participants tended to study, interact and work most with members of their ethnic group. While the participants generally believed that UK-derived cultural capital could improve their chances of highly paid employment, they acknowledged that positional opportunities were limited in arenas where there was poor representation of their respective ethnic group. My participants were generally orientated towards academic programmes, social relationships and work arenas that largely reflected the distinctive majority-minority divide in Malaysia. While linked to ethnicity, relevant participants believed that their nationality was a more significant factor for exclusion in the UK labour market.

My focus on ethnicity is to allow for a more in-depth analysis of one key theme in my findings than is possible with surface-level investigation of numerous overlapping social categories. This is not to ignore that individuals are likely to occupy multiple intersectional positions which have impact on cultural capital pursuits and deployment. I will briefly discuss the effects of nationality and religion as they relate to ethnicity, cultural capital exchangeability and life chance (dis)advantages. Issues related to ethnicity are considered sensitive by government authorities in Malaysia, the discussion of which in local public and academic discourse is limited by legal and institutional sanctions, and self-censorship (Weiss 2011). This article represents a modest contribution to shed some light on Malaysian ethnicity and the reproduction of (dis)advantage in the liberty of a more open international space and discourse.

\section{Contextual Background on Equity and Inequality in Malaysia}

2.1 Research involving Malaysians is interesting as it brings out the complexities of distinction among individuals from a diverse and stratified society amidst the backdrop of widened access to international education. A former British colony which became independent in 1957, Malaysia features a diverse population of different cultures, languages and religions intersecting primarily class and ethnic divisions. The basic official ethnic classification divides citizens into two categories: the bumiputera majority (Sanskrit: 'son of the soil') which comprises groups the government recognises as having cultural affinities indigenous to the South East Asian region and the non-bumiputera minority which refers to groups with immigrant ancestry and whose cultural affinities lie outside the region (Hwang 2003:4). The bumiputeras consisting of the Malays, the indigenous peoples of Peninsular Malaysia and the natives of Sabah and Sarawak form close to $68 \%$ of the Malaysian population (Department of Statistics Malaysia 2013). Malaysians of Chinese, Indian and other descents who constitute the non-bumiputera category represent approximately $24 \%, 7 \%$ and $1 \%$ of the national population (Department of Statistics Malaysia 2013). The Malay language is the national language and Islam, the official religion, the practice of which is constitutionally required by law for the Malays. Malay Muslims, the largest group within the bumiputera majority dominate the political and cultural arenas. They have a lower economic position relative to the Chinese non-bumiputeras who control about $65 \%$ of economic activities and are the wealthiest ethnic group in Malaysia (Jakobsen 2015). The Indian minority is historically a marginalised group in the economic, political and cultural realms (Cangià 2014). Although there is interaction and mixing between ethnic groups, inter-ethnic relations in Malaysia tend to be superficial, characterised by distrust, fear and a lack of knowledge of shared histories and cultures, and the nation's rich diversity (Pillai 2015:xvi).

2.2 A prime reason behind the distanced relations, especially between the ethnic majority and minority groups, lies in ethnicised politics surrounding the state's social engineering (Pillai 2015). Malaysia is unique in that its federal constitution forms the basis for preferential treatment for the ethnic majority particularly in the 
socio-economic sphere. It is among 16 countries in the world which has not ratified the United Nation's International Convention on the Elimination of All Forms of Racial Discrimination (United Nations Human Rights Office of the High Commissioner 2016). Following ethnic riots in 1969, the Malay-led coalition government intensified measures to correct inter-ethnic imbalances in income and wealth especially between the economically inferior Malays and relatively affluent Chinese minorities. Although the constitution provides provisions for the safeguarding of the interests of other ethnic communities, the implementation of affirmation action under the New Economic Policy in 1971 and subsequent national development plans has tended to favour the bumiputeras (Lee 2012). Special privileges are accorded to thebumiputeras notably in forms such as preferential access into certain public higher educational institutions, scholarships and loans for university education, public sector work, professional and managerial positions in public and state-linked institutions, and ownership of assets and corporate equities (Lee et al. 2013). An ethnic-based quota system was in place for entry into public universities until 2001 , allocating $55 \%$ of places to the bumiputeras and $45 \%$ to the non-bumiputeras (Hwang 2003). This has been replaced with a more merit-based entry system for almost all public universities (Joseph 2014). However, decades of policies and practices which favour the ethnic majority have led to the identification of the public higher education sector as the preserve of particularly Malay students (Aihara 2009). In contrast, ethnic minority students largely concentrate in the private sector or further their studies overseas where entry into tertiary education is primarily determined by financial and academic abilities (Lee 2004). Estimates show that close to $70 \%$ of students in the Malaysian public sector arebumiputeras while a similar proportion in the private sector where UK education providers operate are non-bumiputeras (Aihara 2009).

2.3 A similar pattern of ethnic segmentation is reproduced in employment pathways. Bumiputera graduates from local public higher learning institutions tend to move on to public sector employment where they dominate professional and managerial positions (Lee 2012). On the other hand, non-bumiputera graduates from especially local private and overseas institutions are more likely to enter the private sector where similar high-level positions are more attainable (Lee 2012). The public sector is dominated by a single ethnicity and religion, that is, Malay and Islam, by close to $80 \%$ (Ling 2012) while the private sector absorbs the majority of non-bumiputeras. Lack of valid and reliable measures to evaluate the progress of ethnic-based affirmative action has led to open-ended implementation with no clear target objectives and dates (Holst 2012). The perpetuation of ethnically inequitable opportunity structures has been cited by the World Bank (2011) as a key reason for the out-migration of about one million Malaysians for work and settlement overseas, the majority of whom are Chinese. One third of the Malaysian diaspora are tertiary-educated (World Bank 2011). Government efforts to reverse the outflow of human and economic capital have resulted in structural reforms since 1996 to expand the Malaysian private higher education sector (Lee 2004).

2.4 A significant feature of this expansion is the widened availability of mostly undergraduate Western university programmes in local private higher educational institutions and relatively new branch campuses of foreign universities in Malaysia. New modes of international education allow students to undertake their studies entirely or mostly in Malaysia, culminating in the same degree award from the foreign university as conferred on students who study entirely abroad (British Council 2014). The primary target group of educational consumers is individuals from more modest middle-class background who have sufficient access to economic capital to afford international education in the home country, but would be financially constrained if they were to study overseas for an extended duration ( $\operatorname{Sin} 2013$ ). The popular 3+0 study route enables the completion of a three-year undergraduate programme without going overseas. Although new and traditional modes of international education have offered Malaysians increased opportunities to obtain university education, ethnic and class differentials in life chance choices and trajectories remain prevalent (Sin 2013). It is within this context that the students and graduates in my study interpreted and acted out understandings of distinction.

\section{Qualitative Interviewing in Malaysia and the UK}

3.1 The study on which this article is based involved primary interviews with 36 Malaysian students and recent graduates of UK universities. Data collection was conducted between September 2010 and April 2011. Qualitative semi-structured interviewing was used for private, face-to-face interviews with 30 participants. Geographical and time constraints necessitated a focus group with four participants, an audio interview with a participant on Skype and written interviews with one other participant. The average length of the face-to-face and focus group interviews was an hour while the written interviews took place three times over a week. represented with 18 from each gender. 21 participants were either studying or have completed their education in a foreign branch campus of a UK university in Malaysia or in Malaysian private higher educational institutions which offer joint and franchised UK programmes. A further 15 participants studied and finished their programmes in the UK. Participants were recruited through assistance from lecturers and administration staff, student associations, research advertisements and introduction from early interviewees. 
I made sure to have participants of varying characteristics, especially in terms of mode of international education, ethnicity, academic programme and occupation to gain a good range of comprehensive data. By including individuals who studied their programmes partially or entirely in the UK and Malaysia, I had interviewees from both established and more modest middle-class backgrounds. I had 22 Chinese, eight Malays, two Indians, a Punjabi, a Malay of mixed ethnicity and a Sino-Kadazan (mix of Chinese and a native ethnic group in Borneo) in my sample. The disproportionate representation of non-bumiputeras was not surprising as participation in international education is most prevalent among Chinese Malaysians.

3.4 The participants mainly pursued the subject areas of commerce, engineering and information technology which are conventional by Malaysian standards. The number of UK universities represented in the sample amounted to 17. This includes old institutions such as Cambridge, the London School of Economics, Manchester and Sheffield, and new institutions such as Staffordshire, Oxford Brookes, Wolverhampton, Hertfordshire and Nottingham Malaysia. Graduate participants were involved in different forms of work such as paid full-time employment, part-time contracted work, free-lancing and self-employment. Face-to-face interviews were conducted in the UK in London, Edinburgh and Manchester, and in Malaysia in Kuala Lumpur, Petaling Jaya and Penang. These are locations with a high concentration of Malaysians involved in UK education.

Although care was taken to achieve a diverse group of interviewees, my sample may not be entirely representative of all Malaysians presently or previously engaged in UK international education. My aim was to explore in an in-depth manner some of the practices, views and relations of my participants as they anticipated and experienced the conversion of their education-related cultural capital into distinction. With this regard, my research provided details to the complexities of cultural capital exchangeability across stratified spaces of UK international education and graduate employment.

\section{Pursuit of ethnically acceptable disciplines}

4.1 A key complexity of cultural capital pursuits among my participants involved engaging in international education in ways that were aligned not just to classed but also ethnicised expectations of them. Expectations were often set by the participants' parents who usually as authority figures in the family and the main or sole source of funding for their studies had bearing on the participants' accumulation of cultural capital. For Grace (Own business, 3+0 Applied Accounting, Oxford Brookes), it meant choosing a practical discipline which would lead to a 'safe' and unmistakably middle-class profession valued among the Chinese Malaysian community. Furthermore, she had to ensure that the cultural capital gained through her UK education provided accreditation from regulatory bodies which would boost her credibility and exclusivity in the job market:

\footnotetext{
Because I come from a Chinese family, my father said there is only 3 choice...Just architecture, accounting or lawyer. The reasoning is he feels that any other studies, right, any Tom, Dick and Harry can do it but those things that he just mentioned, you need a recognition from the government to be a practitioner over here [Malaysia]. And because of that right, he feels it's value added.
}

4.2 The valuing and appropriation of cultural capital within international education have an ethnic dimension which operates alongside the more obvious class dimension. The absence of the ethnic dimension makes Bourdieu's concept of cultural capital lacking in its ability to explain variations in the choices and strategies of individuals from advantaged and disadvantaged social locations, and the extent to which they are successful in advancing their social mobility aspirations (Shah et al. 2010; Modood 2004). It leaves the concept vague and general, offering limited insights into the complex processes and patterns of educational and occupational distinction across stratified spheres and spaces (Sullivan 2002). Bourdieu's concept therefore has to be adapted to take into consideration other resources which influence the chances and pathways of social mobility, a key resource being ethnicity (Shah et al. 2010; Modood 2004;Zhou 2015).

Ethnicity plays an important part in shaping my participants' sense of worth and suitability in certain academic and occupational fields. The interview findings show evidence of 'ethnicity at work', the transmission of ethnic norms and values from parents and ethnic communities which moulded the participants' higher education and career choices (Shah et al. 2010:1116). Efforts by a few participants to prioritise personal interest in their decision-making tended to still adhere to perceived ethnic norms on appropriate higher education and occupational choices. A case in point is Francis (3+0 Law, London), an Indian Malaysian student who decided to pursue law due to his flair for history and the English language. Francis felt he had let down his parents, his father a doctor and his mother a lawyer, for not choosing medicine. This is a profession which is known to have a heavy concentration of Indian Malaysians (Rajah 2013). As he explained, 'Indian families in Malaysia, generally, you must have a kid who is doing medicine or is a doctor'. Here he explained the superior economic and symbolic value attached to the medical degree and profession especially among privileged Indian Malaysian families: 
was sitting maybe in the third row with my mum and behind us were about five Indian ladies and it was erm a really nice wedding in a big hotel, so this were well-to-do Indian ladies and they started talking. The first thing they started... ...about was where their kids were studying Medicine. Every single one had a kid who was in Ireland or Russia, India or somewhere. You know, so I guess my mum was disappointed as I deprived her [laughs] of that opportunity to you know, go up and talk to people about where her kid was doing Medicine.

4.4 His decision to study law might still have been shaped by his parents' ethnicised expectations. This is given that law is another profession with distinctively high numbers of Indian Malaysians (Rajah 2013). Perceptions as to what were the key disciplines and professions valued by their ethnic group were subjective and varied slightly among my participants. Their education and work options however were generally centered around areas which in their minds represented middle-class and ethnic respectability. This reflects distinction at the intersection of class and ethnicity. A focus on class-based analysis alone, as Bourdieu had done, would not be able to fully explain the different forms and amount of resources accessible to and activated by individuals of diverse social positionings (Vincent et al. 2012) such as my participants. Just as class, ethnicity was capital (Modood 2004; Shah et al. 2010) for the participants: the norms and values on education obtained through interaction and association with familial and ethnic networks provided motivation and direction to secure superior employment and status.

\section{Selective enhancement of skills and networks by ethnicity}

5.1 The impact of ethnicity is also evident in my participants' selective enhancement of skills and networks during their studies. Their regulated appropriation of cultural and social capital was shaped by their sense of proper place (Bourdieu 1984:474) for their ethnic group in the UK education setting and wider society. Imran, a Malay Muslim studying for a UK degree in Malaysia (3+0 Business Information Technology, Staffordshire), limited his experience of international education to what was considered 'proper' within his family's ethnically and religiously prescribed boundaries. As much as his father encouraged him to develop 'open' and 'independent thinking', Imran was expected to minimise contact with implied Western liberal influences which could compromise traditional Malay Muslim values and identity. As a consequence, Imran opted for a Muslimdesignated student residence run by his university college. The friends he socialised with most in his university college were Malays with whom he spoke in Malay, his habitual language. English was only utilised in his interaction with non-Malay local peers 'if they do not understand what I'm talking'. His selective acquisition and display of cultural capital relates to Joseph's (2009:20) observation of the balancing of traditional and local ethnoreligious embodiment with the appropriation of global cultural forms among young Malay Muslim women she interviewed. Her participants were allowed by their parents to expand their academic and career potential but only under the condition that the honour of their family and ethnic community was safeguarded at all times. Ethnicity impacted on the learning, friendship and interaction patterns of Joseph's participants just as it did for participants in my study. It conditioned my participants' habitus or internalised cognitive and behavioural framework (Bourdieu 1984) through which they developed and acted upon perceptions of what positional and interactional possibilities were valuable and feasible, and what were not.

An ethnicised pattern of interaction broadly similar to social mixing in Malaysia (Chapman \& Pyvis 2006) was transplanted and replicated in the UK among my participants who studied in the UK. Ethnic segregation tended to occur particularly between Malay and non-Malay students even when abroad. Tricia (Charities Officer, $1+2$ Law, Sheffield), a Chinese Malaysian, noticed the social and physical distancing between ethnic majority and ethnic minority Malaysians at her university in Sheffield:

Somehow, the Malay students wanted their own association, so they have their own association [SMSA - Sheffield Malaysian Students Association] but we don't join them. We joined the MASSOC, the Malaysian Singaporean Society. You know, it's sad. At that point already, you can see this spilt between and in my halls of residence during my first year...they [Malays] were pretty much in their own group. So the Malays were like having their own society, doing their own thing. We do our own thing.

5.3 Hussain (University Tutor, MPhil Engineering, Cambridge), a Malay Muslim, observed the same pattern of interaction at Cambridge which broadly divided Malaysians into two ethnic pockets: 'Actually, I [was] hoping that I can hang out with everyone. It turns out that [laughs] mostly most of the times only Malays la...I think the race get segregated. I can hardly see people of different race mingle with each other'. Hussain had 'some but not really close' British friends at university, a few close friends from China but was closest to mainly Malay Muslims from Malaysia for ease in having halal food together. Examples such as these challenge a common assumption of overseas-based international students as globally exposed and readily able to acquire distinct cosmopolitan experiences through interaction with diverse ethnicities and nationalities (Bilecen 2013; Kim 2011). They question a deterministic line of thought in Bourdieu's works (Bourdieu 1984; 1997; Bourdieu \& Passeron 1977) which assumes that the economically privileged has equal and full access to valuable cultural capital, and that individuals will naturally and logically invest in them. The reality is that foreign cultural capital available within international education may not be fully accessed by international students due to their preferences and circumstances (Waters \& Brooks 2011; Matthews \& Sidhu 2005) surrounding their ethnic and intersectional 
Accounts from relevant participants revealed an inclination to associate with students of relatively similar cultural and linguistic backgrounds, reflective of their ethnicity and by some extension, nationality and religion. Their incorporation into 'acceptable difference' in the host country has parallels to Waters and Brooks' findings (2011:572) on the preference of UK students abroad to immerse in an exclusive network of international students from similar backgrounds. Tricia recalled facing difficulties in approaching and entering mainstream social circles in the UK: 'I did try to approach them but it wasn't that kind of response that I was looking for. It wasn't as warm and I didn't want to spend that time to get them to warm up to me'. Setbacks in initiating close inter-personal relations with British students quickly led her to establish and remain within her close networks predominantly made up of Chinese Malaysian students. Challenges cited by the participants in building social networks with British students include differences in culture, lifestyle and ways of speaking, the perceived private nature of British people, and the effort required to be understood beyond stereotypes of the Malaysian as the exotic ethnic 'other' from a distant, less developed country. Selective social mixing along the line of ethnicity intersecting with nationality and religion helped my participants to develop a close network of friends to draw on especially for emotional support and the recreation of food-related practices of their ethnic, cultural and religious groups. However, it would be stretching the argument to suggest that developing strong relationships within a relatively tightly knit network generated maximum benefits (Coleman 1990) for the participants. The downside of investing in relatively similar ethno-cultural and linguistic ties in the host country, social capital which Portes (1998) argued has negative consequences, is that it restricted immersion into cultural capital associated with international education such as cosmopolitan identification and global orientation (Matthews \& Sidhu 2005:50). This had implications on my participants' chances for occupational and status mobility within arenas and sites which valued these forms of capital.

\section{Segregation by ethnicity within public employment in Malaysia}

6.1 Association and exclusion linked to one's ethnicity extended into the arena of graduate employment. My participants believed that ethnicity can facilitate the exchange of education-related cultural capital into acceptance and credibility when positioned in an appropriate sphere and site of employment. They made and reproduced different occupational choices based on perceptions of their ethnic 'fit' (Mushamir, Student, PhD Electronic \& Communication Engineering, Nottingham Malaysia) in certain organisations and sectors in Malaysia. The anticipation of ethnic disadvantage in entry and promotions steered Teik Lee (2.75+0.25 BSc(Hons) Computing \& Information Systems, Liverpool John Moores), a Chinese executive in an international company, away from public sector employment. He believed that to advance in the sector, having the right ethnicity, that is, the right 'colour of skin' was more important than accumulating the right cultural capital from tertiary education. Wah Seong (MSc Civil Engineering student, Nottingham Malaysia), a Chinese student, was attracted to the generous leave provisions and lighter workload in the public sector, but was concerned that his ethnic classification and source country of tertiary education would lower his chances of getting in:

In fact, I hate to say that [laughs], but it does. Especially, if you're applying for the public sector...Everyone knows it [laughs]. They're more inclined to employ the local people...well, if they don't [laughs], I think the local graduates would find it hard to get a job elsewhere'.

'Local' carried two meanings. It referred to bumiputera citizens, particularly the Malays, and to local public university graduates who the participant implied as inferior. This conceptualisation of the local is not uncommon as ethnic minorities tend to associate Malay public university graduates with state dependency, reduced work ethic and inflated credentials given assumed preferential bumiputera treatment in public higher education and public sector employment (Lee and Khalid 2016:69). Malays are favoured by the public sector as the government attempts to absorb the mass of unemployed public university graduates into an already overstaffed sector (Lee 2012; Kaur 2016). Theoretically, this means that the relative exclusivity and scarcity of certain education-related cultural capital do not instantly lead to positive economic and symbolic exchanges in all fields and in the same way for everyone as Bourdieu would have it (Bourdieu 1984; 1997; Bourdieu \& Passeron 1977). A UK degree holder in Malaysia, especially one who is ethnic minority, would likely be excluded from a predominantly ethnic majority public sector workforce with more common and widely accessed local cultural capital. There is a limit to the extent foreign cultural capital obtained from international education can help widen occupational possibilities. It may have a negative exchange value ( $\operatorname{Sin} 2013$ ) in the Malaysian public sector, especially when the individual is systematically relegated to a subordinated ethnic status.

\section{Ethnic segregation within private employment in Malaysia}

7.1 My participants similarly assessed the viability of a career in the Malaysian private sector based on the sector's receptivity towards the inter-linkage between their ethnicity and the cultural capital they owned. Ethnic minority participants, particularly of Chinese origin, preferred to work in the private sector as they believed that they would be better understood and accepted in a sector which has a heavy concentration of their co-ethnics. 
Private Chinese-controlled and multinational companies in Lee and Khalid's study (2016) showed a clear preference to invite Chinese Malaysians for interviews. Lee and Khalid believed that this was likely due to the perceived compatibility of the Chinese with the culture and ethnic composition of the companies which have substantial numbers of Chinese employees. An individual's habitual predispositions towards cultural-linguistic knowledge and skills typically characteristic of the ethnic group can facilitate inclusion in the workplace. Although English is the dominant language of communication in the Malaysian private sector, it is not uncommon for daily workplace communication to be localised by influences from languages and dialects usually indicative of ethnicity (Nair-Venugopal 2000). Mandarin, the language spoken habitually in Kor Ming's (Student, BA(Hons) Accounting \& Finance, UWE) home, and Cantonese, his spoken ethnic dialect, equipped him with cultural-linguistic knowledge which eased his interactions with the many Chinese Malaysian clients he worked with during his internship at an international auditing company:

It's just that sometimes it's communication. Let's say your client only knows how to speak Mandarin. You cannot send someone who doesn't speak Chinese at all. It'll be very tough for him...to some, I speak English. To some, I speak Mandarin and to clients, I speak Cantonese.

7.2 Acquiring these linguistic forms of cultural capital may have more to do with ethnic-based connections and interactions developed through family socialisation than with participation in institutions of formal and higher education. This reminds of the distinction that Reay et al. (2001), in extending Bourdieu's concept of habitus (Bourdieu 1984; Bourdieu \& Passeron 1977), made between the personal and institutional habitus through which individuals internalise a system of dispositions and derive cultural capital.

The local private labour market is a field where Chinese Malaysians (Lee \& Khalid 2016) can accrue positive exchange value and symbolic power (Skeggs 2004) through their personal ethnic habitus and cultural capital. Kelvin (Business Consultant, BSc(Hons) Business Mathematics \& Statistics, LSE), for example, believed that his Chinese ethnicity commanded more instant trust and recognition of his work potential: 'I guess I am lucky because I think in terms of seeking [private] employment and all that, being Chinese in Malaysia, you automatically score a point in terms of how you are viewed as in terms of capability'. His ethnicity symbolised embodiment of a valued Chinese work ethic involving qualities such as ambition, drive and productivity (Joseph 2009) which did not necessarily require activation and display to yield immediate acceptance in the private sector. Kelvin's ascribed membership in a large albeit minority ethnic group, connected by norms of habitual trust and confidence in its members, enabled him to enjoy economic and symbolic opportunities that were not as readily available to smaller ethnic minority groups. Nevertheless, the Indian and Punjabi participants in my study believed that they had good opportunities for economic advancement in the private sector if they showed that they too valued hard work, performance and excellence, markers historically but not exclusively linked to the collectively owned cultural capital of the Chinese community (Joseph 2009). Participation in the private sector was for the Chinese and other ethnic minority participants a strategy to counter the devaluation (Skeggs 2004) of their cultural capital, both ethnic and class-related, that they would likely face in the rigid and insular public sector. It offered them power and opportunities to mobilise their cultural capital including their UK education to secure good jobs and status, despite their overall subordinated position within a heavily ethnicised social hierarchy in Malaysia. This is a possibility which Bourdieu was unlikely to entertain as he gave very little agency to disadvantaged groups to challenge power relations (Skeggs 2004).

7.4 The findings do not suggest that being ethnic majority has little advantages in the private sector. Hussain, a Malay university tutor (MPhil Engineering, Cambridge) described how his ethnicity was valued for diversity reasons: 'At first, I believed they don't care about it. But once I talked to my boss, they say they still encourage Malays to join'. While Hussain did not mention this, it is common knowledge that his ethnicity is favoured in bumiputera-owned private companies as professional and managerial roles are reserved for his ethnic group (Lee et al. 2013). His ethnicity is also an advantage in non-bumiputera controlled companies which seek out bumiputera partners to secure government-tendered contracts and licences (ee et al. 2013). Elaine (Student, BA (Hons) Business, Economics \& Management), believed that her bumiputera status by virtue of being part Kadazan, an indigenous group in Borneo, and her part-Chinese parentage positioned her well for recruitment in both bumiputera and non-bumiputera private companies. However, she believed she still faced discrimination in bumiputera-controlled companies as her 'in between' ethnic position could be judged as less indigenous as compared to ethnic and national memberships historically and politically linked to an imagined panMalay nation (Clark \& Pietsch 2014):

I felt that it [ethnicity] did matter a little bit because TM [Telekom Malaysia] had internships...my qualifications were better than the other person I know who applied...she is Indonesian, but they still selected her.

It is clear that ethnicity has an exchange value of its own (Shilling 2005) which to some extent, is derived somewhat naturally from having being born and labelled into certain socially constructed ethnic groups. Whether anticipated or experienced in actuality, ethnicity can contribute to success and failure in acquiring positions of advantage across the public-private employment divide in Malaysia. Nevertheless, my participants would agree 
with Bourdieu (1984) that long-term substantial development of cultural capital through education was important to improve life chance opportunities.

\section{The Ambiguous Effects of Ethnicity in the UK}

8.1 Ethnicity was perceived by participants who studied in the UK as less influential for economic inclusion in the host country. This was because labour market policies, on the surface, encouraged equal opportunities for employment on the basis of the individual's merit, ability and qualifications. Noraini (MSc Oil \& Gas Engineering, Robert Gordon), a Malay well engineer in Aberdeen, spoke of how it was unlawful in the UK for employers to discriminate ethnic minority applicants by personal characteristics. She believed that equality of employment based on the perceived quality and worth of the candidate's education-related cultural capital was at least practised in the first stage of candidate screening. She noted that 'you can gauge how marketable you are by the number of calls you get which presumably will be without prejudice'. The recent pledge by the civil service and major graduate employers in the UK to introduce name-blind applications, that is, recruitment without asking for the candidate's name (Cameron 2015), seems to support Noraini's observation. Negative bias and discrimination, if suspected or experienced, was believed by Noraini to be more common in later stages of application where the ethnicity of the candidate was known with more certainty in face-to-face interviews.

8.2 Brian (PhD Electrical Engineering, Cambridge), a Chinese researcher at a government agency in Kuala Lumpur, made a distinction between meritocracy as policy and meritocracy as practice in the UK. He believed that a policy encouraging ethnically equitable employment opportunities could differ from practice. He noted that recruitment in the UK tended to be positively biased towards candidates from affluent white backgrounds:

$\mathrm{Ar}$, in fact, I used to argue with my British friends, right, discrimination in the UK is worse than discrimination in Malaysia...over here [Malaysia], it is transparent. We discriminate people but according to the law. Our constitution says discriminate, so we discriminate. Ok? Over there, on paper, everybody is equal. But some people are more equal than others. WASPs, the White Anglo-Saxon Protestants will be more advantaged than other guys...so, it still happens. But over there, on paper, you know, everyone there is equal.

8.3 Current employment trends in the UK confirm Brian's observation. White male local candidates with private school education and degrees from prestigious universities are favoured by employers, especially elite professional service firms (Ashley et al. 2015). In contrast, UK-domiciled Black, Asian and ethnic minority graduates are more likely to be unemployed and earn less than white graduates, regardless of their socioeconomic background, qualifications and academic performance (TUC 2016; Zwysen \& Longhi 2016; LessardPhillips et al. 2014). It is uncertain whether Brian experienced any real ethnic discrimination in the UK as he returned to Malaysia right after graduation to serve his scholarship bond. Nevertheless, the unwritten rules of employment and advancement in the host country can be, to use Brian's words, less 'transparent', given that it may be more difficult to identify when an individual is unfairly treated due to ethnicity. Ethnicity may still influence chances of employment and advancement in the UK for foreign graduates, although how it works to do so is less clear cut and identifiable. What is clear is that education-related cultural capital alone is not enough for ethnic minorities (Lessard-Phillips et al. 2014) including non-EU international graduates to negate the subtle and systemic disadvantages that they face in the UK labour market.

\section{The More Significant Role of Nationality in the UK}

9.1 Unlike ethnicity, exclusion on the basis of nationality in the UK labour market is more obvious and outright. Most participants who studied in the UK found it difficult to obtain graduate work due to their nationality status as non-citizens of the European Economic Area (EEA) and Switzerland. Political-legal lack of preference for labour migrants originating from outside the EEA and Switzerland (Olad \& Grove-White 2015; Mellors-Bourne et al. 2013) constrained the conversion of education-related cultural capital to institutionalised right to work and live indefinitely in the host country. This essentially 'shut down....almost all the opportunities' for Eng Hock (Bachelor of Medicine/Surgery, Sheffield) after his two-year foundation training as trainee doctor in Sheffield. It became difficult for him to obtain specialist training positions in the UK, prompting him to return to Malaysia. The ever changing and tightening immigration rules in the UK heighten the volatility of the marketability of certain international graduates, Peng Suan, (BSc(Hons) Government \& Economics, LSE), being one of them. A sales and operation manager with an international oil company in London, she was periodically reminded of her temporality in the UK, having had her work visa changed three times in four years to comply with immigration rules. It is clear here how an unfavourable nationality status complicated her utilisation of education-related cultural capital for economic capital in the host country.

This is not to say that nationality does not offer labour market opportunities to foreign graduates working in the UK. Peng Suan (BSc(Hons) Government \& Economics, LSE) and Jia Wen (Multiple Jobs, BA(Hons) Politics \& IR, Manchester) believed that their national and regional origin complemented their respective companies' internationalisation strategy to expand to Asia, making them a valuable addition. Coming from a different national and cultural background can be constructed as a 'story' (Peng Suan) which speaks of ability to 
adapt well to new and unfamiliar situations in an international setting. Nationality can also act as an indicator of access to habitually acquired insider knowledge of the home country and the surrounding region, cultural capital which is often not transmitted through international education. Jia Wen (Multiple Jobs, BA(Hons) Politics \& IR, Manchester) believed that her nationality and the fact that she grew up in Asia helped her secure her upcoming employment as writer for a UK-based travel website specialising in Asian destinations. Both participants were able to capitalise on the cultural and symbolic value attached to their geographical origin, and find their advantaged place in appropriate fields (Skeggs 2004) despite their political and legal disadvantages in the UK labour market. The key point, nevertheless, is that strict immigration policies in the UK significantly restrict opportunities for non-European Union (EU) foreign graduates to exchange their education-related cultural capital for legitimacy to work in the host country. New rules from April 2016 require a majority of non-EU foreigners who have worked in the UK for more than five years to earn at least GBP35000, failure of which will result in deportation (Home Office 2015). This will intensify barriers to work permit employment, more so should these rules ever extend to include EU nationals. For now, there are no immediate changes to the rights of EU nationals to work and live freely in the UK following Britain's exit from the European Union (Gov.uk 2016). The exclusionary effects of nationality status are most likely to be felt first long before ethnicity may become an issue of concern for job search and advancement in the UK. All in all, there are social divisions other than class which shape life chance possibilities and actualities for international students and graduates. It would be difficult and perhaps impossible to study the link between education-related cultural capital and distinction independently from ethnicity and other dimensions of differentiation.

\section{Conclusion}

10.1 In this article, I have discussed the under-researched role of ethnicity in shaping the conversion of cultural capital linked to UK international education into positions of (dis)advantage. My contribution is that I sensitised the use of Bourdieu's concept of cultural capital by moving beyond a heavy focus on class to include ethnicity and where relevant, its interconnection with nationality and religion. In doing so, I challenged a common treatment of foreign students and graduates as homogeneous groups, subsumed under the single category of the middle class. While foreign students and graduates may be seen as a privileged class of educational consumers, their different assigned and assumed positions in society pose varying degrees of constraints on them in their pursuit and use of education-related cultural capital. By situating Bourdieu's concept of cultural capital into the context of UK-educated Malaysians, I brought out some of the variations and complexities of distinction across the stratified arenas and sites of UK international education and graduate employment. The article articulated the largely unspoken, at least publicly in Malaysia, the issues and challenges of ethnic mobility and incorporation among Malaysians. While Bourdieu's concept of cultural capital is useful to explain the advantaged position of the dominant class within structures of power, differentiation and inequality, the findings in this article show that a narrow focus on class can only provide partial understanding of distinction among individuals of diverse social positionings who are at once, privileged and disadvantaged. It is not able to explain why exclusive cultural capital acquired through international education do not produce equal outcomes for all who possess it, and why the outcomes may not necessarily be positive in all fields. The findings accounted for this gap, effectively shedding light on how ethnic-related capital mediate the accumulation and exchange of cultural capital linked to international education, and result in positional (dis)advantages that are relative and contingent. They show that cultural capital embedded in resources other than class can reproduce economic and symbolic rewards for members of privileged groups in some fields but not so in other fields where the individuals occupy positions of less dominance. The findings which reflect intended and actual usage of varied forms of cultural capital highlighted the possibility and strategy of individuals from excluded groups to challenge and work around their disadvantage. This represents an improvement over Bourdieu's concept of cultural capital which had little to say about the potential for social mobility among individuals from the disadvantaged side of social divisions. The findings essentially contribute to knowledge on the relevance and transferability of Bourdieu's concept of cultural capital to the diverse and stratified global education and labour market landscape.

10.2 The unprecedented growth of the international education industry, especially through transnational delivery has provided Malaysians of various ethnicities with some equity of access to higher education. However, as my findings have shown, long standing wider structures in Malaysia continue to reinforce ethnic inequality, segmentation and exclusion. Although ethnicity is a key driver of (dis)advantage for Malaysians apart from class, it is important to remember that there are more intertwining divisions which influence distinction. Nationality and religion, which were discussed less in this article, can simultaneously structure cultural capital accumulation and activation, as can gender and age. A possible direction for future articles is to explore other social divisions and their impact on the exchangeability of cultural capital.

10.3 Persisting ethnic differentials in education aspirations, experiences and outcomes challenge UK universities to do more in promoting equity and inclusiveness both in the UK and in countries where its universities operate. It is not simply a matter of widening access to students from traditionally disadvantaged backgrounds, but to ensure that programmes, services, facilities, sites and activities are helping both privileged 
and disadvantaged individuals to widen academic, socio-relational and economic opportunities unencumbered by ethnicity and other categories of division. It requires UK universities to reflect critically on their role in reproducing structures and relations of domination and subordination, and consider how they can change internal and wider practices which reinforce and exacerbate social divisions. While the divisive effects of ethnicity among Malaysians are not new, they are now more visible within UK education as universities accept more Malaysian students through their overseas branch campuses and/or partnerships with Malaysian private providers. It is more important than ever for UK universities to actively take on their role in social transformation to challenge and break down barriers which limit a more equitable participation of individuals in society. Existing government and institutional policies and practices in the UK which readily divide students and graduates into the binary categories of home/international and legitimate the segregation of opportunities, spaces and activities such as separate accommodation (Peacock \& Harrison 2009) and significant differences in tuition fees and employment conditions (Olad \& Grove-White 2015; Mellors-Bourne et al. 2013) hamper positive development in this respect. In addition, a dominant neo-liberal approach to internationalisation which markets an ethos of equity, diversity and inclusiveness, but at the same time, privileges UK cultural capital (Sidhu 2006) limits the potential of universities to transform hierarchies of differentiation and exclusion. Complicating this further is the challenge of managing competing agendas and interests with stakeholders especially in countries of transnational delivery whose collaboration and partnership UK universities depend on for the expansion and diversification of revenue (Healey 2016). The extent to which UK universities can and are prepared to put pressure on stakeholders to collectively address deep-rooted policies and practices of segregation, bias and discrimination within a restrictive ethno-political environment such as Malaysia is an important and interesting topic for future research. A way forward to narrow social divisions and gaps of (dis)advantage is to study the complexities of cultural capital exchangeability where ethnicity interplays with other diversities to structure life chance possibilities.

\section{References}

HOLST F, (2012) Ethnicization and Identity Construction in Malaysia. Abingdon: Routledge.

JOSEPH, C. (2009). 'Postcoloniality and Ethnography: Negotiating gender, ethnicity and power',Race, Ethnicity and Education, Vol. 12, No.1, p. 11-25.

KAUR, M. (2016). Number of Unemployed Public University Graduates to Soar, Free Malaysia Today21 June 2016. Available online: http://www.freemalaysiatoday.com/category/nation/2016/06/21/number-ofunemployed-public-university-graduates-to-soar (Accessed 21 November 2016).

UNITED NATIONS HUMAN RIGHTS OFFICE OF THE HIGH COMMISSIONER(2016). 'Status of Ratification' http://indicators.ohchr.org. Accessed 21 November 2016.

AlHARA, A. (2009) 'Paradoxes of Higher Education Reforms: Implications on the Malaysian middle class', International Journal of Asian Pacific Studies Vol. 5, No. 1, p. 81-113.

ASHLEY, L., Duberley, J., Sommerlad, H. and Scholarios, D. (2015). 'A Qualitative Evaluation of NonEducational Barriers to the Elite Professions' https://www.gov.uk/government/uploads/system/uploads/attachment_data/file/434791/A_qualitative_evaluation_of_noneducational_barriers_to_the_elite_professions.pdf. Accessed 13 July 2016.

BILECEN, B. (2013) 'Negotiating Differences: Cosmopolitan experiences of international doctoral students', Compare: A Journal of International and Comparative Education Vol. 43, No. 5, p. 667-688.

BOO, S L. (2013). NGOs to Putrajaya: Ratify Human Rights Treaties, The Malay Mail 9 December 2013.

BOURDIEU P, (1998) Practical Reason. Stanford: Stanford University Press.

BOURDIEU P (1997) The forms of capital in Halsey A, Lauder H, Brown P and Wells A S (Eds.)Education: Culture, Economy and Society, Oxford: Oxford University Press.

BOURDIEU P, (1984) Distinction: A Social Critique of the Judgement of Taste. New York and London: Routledge.

BOURDIEU P and Passeron J C, (1977) Reproduction in Education, Society and Culture. London and Beverley Hills: Sage Publications.

BRITISH COUNCIL (2014) Study for a UK Qualification Outside the UK http://www.educationuk.org/malaysia/articles/uk-qualifications-overseas. Accessed $6^{\text {th }}$ March 2016. 
CAMERON D. (2015) The Conservatives Have Become the Party of Equality, The Guardian 26th October 2015. Available online: http://www.theguardian.com/commentisfree/2015/oct/26/david-cameron-conservativesparty-of-equality (Accessed 15th February 2016).

CANGIÀ, F. (2014). 'The Hindu rights action force and the definition of the "Indian Community" in Malaysia', Sociological Research Online Vol. 19, Issue 4: http://www.socresonline.org.uk/19/4/3.html.

CHAPMAN, A. and Pyvis, D. (2006) 'Quality, Identity and Practice in Offshore University Programmes: Issues in the internationalisation of Australian higher education', Teaching in Higher Education Vol. 11, No. 3, p. 233-245.

CHOOI, C. (2011). Pua: Budget 2012 Failed to Deliver on Reforms, The Malaysian Insider 7 October 2011. Available online: http://www.themalaysianinsider.com/malaysia/article/pua-budget-2012-failed-to-deliveron-reforms (Accessed 15 November 2015).

CLARK M and Pietsch J, (2014) Indonesia-Malaysia Relations: Cultural Heritage, Politics and Labour Migration New York: Routledge.

COLEMAN, J. (1988). 'Social Capital in the Creation of Human Capital', The American Journal of Sociology, Vol. 94, p. 95-120.

DEPARTMENT OF STATISTICS (2013) 'Population Projections: Malaysia 2010-2040'

http://www.statistics.gov.my/portal/download_Population/files/population_projections/Population_Projection_20102040.pdf. Accessed 31 January 2016.

GU, Q. and Schweisfurth, M. (2015). 'Transnational Connections, Competences and Identities: Experiences of Chinese international students after their return 'home", British Educational Research Journal Vol. 41, No. 6, p. 947-970.

HEALEY, N. (2016). 'The Challenges of Leading an International Branch Campus: The "lived experience" of incountry senior managers', Studies in International Education Vol. 20, No. 1, p. 61-78.

HOME OFFICE (2016). 'Statement: The status of EU nationals in the UK' https://www.gov.uk/government/news/statement-the-status-of-eu-nationals-in-the-uk. Accessed 13 July 2016.

HOME OFFICE (2015). 'Immigration Rules Changes' https://www.gov.uk/government/news/immigration-ruleschanges. Accessed 29 October 2015.

HWANG I W, (2003) Personalised Politics: The Malaysian State under Mahathir. Singapore: Institute of Southeast Asian Studies.

JAKOBSEN M, (2015) Ethnic Chinese Entrepreneurship in Malaysia: On Contextualisation in International Business Studies. Abingdon: Routledge.

JOSEPH C, (2014) Growing Up Female in Multi-Ethnic Malaysia Oxon: Routledge.

KIM, J. (2011) 'Aspiration for Global Cultural Capital in the Stratified Realm of Global Higher Education: Why do Korean students go to US graduate schools?', British Journal of Sociology of Education Vol. 32, No. 1, p. 109-126.

LEE, H A (2012) Affirmative action in occupational representation: policies and outcomes in Gomez E T and Saravanamuttu J (Eds.) The New Economic Policy in Malaysia: Affirmative Action, Ethnic Inequalities and Social Justice, Singapore: NUS Press and ISEAS.

LEE, H A, Gomez E T and Yacob S (2013) Ethnicity, economy and affirmative action in Malaysia' in Gomez E T and Premdas R (Eds.) Affirmative Action, Ethnicity and Conflict, London and New York: Routledge.

LEE H A and Khalid A M (2016) 'Discrimination of High Degrees: Race and graduate hiring in Malaysia',Journal of the Asia Pacific Economy, Vol. 21, No. 1, p. 53-76.

LEE M, (2004) Restructuring Higher Education in Malaysia Penang: Universiti Sains Malaysia.

LESSARD-PHILLIPS, L., Swain, D., Pampaka, M. and Nwabuzo, O. (2014). 'When Education Isn't Enough: Labour market outcomes of ethnic minority graduates at elite universities' http://www.runnymedetrust.org/uploads/WhenEducationlsntEnough.pdf. Accessed 13 July 2016. 
LING, S. (2012) Ethnic Minority Groups in Federal Civil Service Lacking, The Star, 29 August 2012.

MATTHEWS, J. and Sidhu, R. (2005). 'Desperately Seeking the Global Subject: International education, citizenship and cosmopolitanism', Globalisation, Societies and Education, Vol. 3, No. 2, p. 49-66.

MELLORS-BOURNE, R., Humfrey, C., Kemp, N. and Woodfield, S. (2013). 'The Wider Benefits of International Higher Education in the UK'

https://www.gov.uk/government/uploads/system/uploads/attachment_data/file/240407/bis-13-1172-thewider-benefits-of-international-higher-education-in-the-uk.pdf. Accessed 13 July 2016.

MODOOD, T. (2004). 'Capitals, Ethnic Identity and Educational Qualifications', Cultural Trends, Vol. 13, No. 2, p. 87-105.

NAIR-VENUGOPAL, S. (2000). 'English, Identity and the Malaysian Workplace', World Englishes, Vol. 19, No. 2, p. 205-213.

NG, E. (2013). MCA Calls for Review of Affirmative Action Policies, The Malaysian Insider, 2 December 2013. Available online: http://www.themalaysianinsider.com/malaysia/article/mca-calls-for-review-ofaffirmative-action-policies. (Accessed 15 November 2015).

OLAD, A. and Grove-White, R. (2015). 'UK Post Study Work Opportunities for International Students' http://www.appgmigration.org.uk/sites/default/files/APPG_PSW_Inquiry_Report-FINAL.pdf. Accessed 13 July 2016.

PEACOCK, N. and Harrison, N. (2009). 'It's So Much Easier to Go with What's Easy: "Mindfulness" and the discourse between home and international students in the United Kingdom', Journal of Studies in International Education, Vol. 13, No. 4, p. 487-508.

PILLAI, P, (2015) Yearning to Belonging: Malaysia's Indian Muslims, Chitties, Portuguese Eurasians, Peranakan Chinese and Baweanese. Singapore: ISEAS-Yusof Ishak Institute.

PORTES, A. (1998). 'Social Capital: Its Origins and Applications in Modern Sociology',,Annual Review of Sociology, Vol. 24, p. 1-24.

RAJAH, M. (2013) Unite as a Community, The Star, 23 November 2013.

REAY, D., David, M. and Ball, S. (2001). 'Making a Difference?: Institutional habituses and higher education choice', Sociological Research Online, Vol. 5, No.4: http://www.socresonline.org.uk/5/4/reay.html.

SHAH, B., Dwyer, C. and Modood, T. (2010). 'Explaining Educational Achievement and Career Aspirations among Young British Pakistanis: Mobilising 'ethnic capital'?', Sociology, Vol. 44, p. 1109-1127.

SHILLING C, (2005) The Body in Culture, Technology and Society. London, Newbury Park and New Delhi: Sage Publications.

SIDHU, R, (2006) Universities and Globalization: To Market, to Market New Jersey: Lawrence Erlbaum Associates.

SIN, I L. (2013). 'Cultural Capital and Distinction: Aspirations of the "other" foreign student',British Journal of Sociology of Education, Vol. 34, No. 5-6, p. 848-867.

SIN, I L. (2009). 'The Aspiration for Social Distinction: Malaysian students in a British university',Studies in Higher Education, Vol. 34, No. 3, p. 285-299.

SKEGGS, B. (2004). 'Exchange, Value and Affect: Bourdien and 'the self", The Sociological Review, Vol. 52, No. 2, p. 75-95.

SULLIVAN, A. (2002). 'Bourdieu and Education: How useful is Bourdieu's theory for researchers?', Netherlands Journal of Social Sciences, Vol. 38, No. 2, p. 144-166.

TRADE UNION CONGRESS (TUC) (2016). 'Black, Qualified and Unemployed' https://www.tuc.org.uk/sites/default/files/BlackQualifiedandunemployed.pdf. Accessed 13 July 2016.

UNESCO INSTITUTE FOR STATISTICS (2014). 'Browse by Theme' http://www.uis.unesco.org/DataCentre/Pages/BrowseEducation.aspx. Accessed 7 March 2016.

VINCENT, C., Rollock, N., Ball, S. and Gillborn, D. (2012). 'Intersectional Work and Precarious Positionings: Black middle-class parents and their encounters with schools in England', International Studies in 
Sociology of Education, Vol. 22, No. 3, p. 259-276.

WATERS, J. (2006). 'Geographies of Cultural Capital: Education, international migration and family strategies between Hong Kong and Canada', Transactions of the Institute of British Geographers, Vol. 31, No. 2, p. 79-192.

WATERS, J. and Brooks, R. (2011). 'Vive La Difference?: The 'international' experiences of UK students overseas', Population, Space and Place, Vol. 17, No. 5, p. 567-578.

WATERS, J. and Leung, M. (2013). 'Immobile Transnationalisms? Young people and their in situ experiences of "international" education in Hong Kong', Urban Studies, Vol. 50, No. 3, p. 606-620.

WATERS, J. and Leung, M. (2012). 'Young people and the reproduction of disadvantages through transnational higher education in Hong Kong', Sociological Research Online Vol. 17, Issue 3:

http://www.socresonline.org.uk/17/3/6.html.

WEISS, M, (2011) Student Activism in Malaysia: Crucible, Mirror, Sideshow. New York: Cornell Southeast Asia Program Publications.

WORLD BANK (2011). 'Malaysia Economic Monitor: Brain Drain'. http://documents.worldbank.org/curated/en/2011/04/14134061/malaysia-economic-monitor-brain-drain. Accessed 15 October 2015.

ZHOU, M (2015) Ethnicity as social capital: community-based institutions and embedded networks of social relations in Loury G, Modood T and Teles S M (Eds.) Cambridge: Cambridge University Press.

ZWYSEN, W. and Longhi, S. (2016). 'Labour Market Disadvantage of Ethnic Minority British Graduates: University choice, parental background or neighbourhood?' https://www.iser.essex.ac.uk/research/publications/working-papers/iser/2016-02.pdf. Accessed 13 July 2016. 